\title{
Review : Stabilitas Bahan Alam dalam Mikroenkapsulasi
}

\author{
Reza Pratama ${ }^{1,2, *}$, Marline Abdassah ${ }^{1}$, Anis Yohana Chaerunisaa ${ }^{1}$ \\ 1Departemen Farmasetika dan Teknologi Farmasi, Fakultas Farmasi, Universitas Padjadjaran, \\ Jatinangor 45363 \\ ${ }^{2}$ Kelompok Keilmuan Farmasetika dan Teknologi Farmasi, Fakultas Farmasi Universitas Bhakti \\ Kencana, Bandung, 40614 \\ *Email: reza19001@mail.unpad.ac.id
}

(Submit 24/4/2021, Revisi 9/62021, Diterima 5/7/2021, Terbit 8/7/2021)

\begin{abstract}
Abstrak
Mikroenkapsulasi merupakan teknologi menyalut bahan inti yang digunakan sebagai teknik perlindungan bahan inti dari pengaruh lingkungan, meningkatkan stabilitasnya, menutupi bau dan rasa, dan juga dapat mempertahankan sifat asli dari bahan inti yang dienkapsulasi. Dari beberapa penelitian bahan alam memiliki kelemahan dalam stabilitas penyimpanannya sehingga mikroenkapsulasi dapat menjadi pilihan untuk mejaga setabilitasnya. Metode pembuatan mikroenkapsulasi dibedakan menjadi beberapa proses secara Kimia, Fisika-Kimia dan Fisika. Artikel ini dibuat menggunakan metode dan referensi yang didapat dari beberapa database dan instrumen pencarian secara online yang diterbitkan secara nasional dan internasional. Referensi yang didapatkan berasal dari database elektronik seperti google scholar, sciendirect, MDPI, $N C B /$ dari tahun 2007-2020. Artikel ini akan membahas stabilitas dari bahan alam yang dibuat ke dalam bentuk mikroenkapsulasi. Dari beberapa penelitian menggunakan bahan inti yang berasal dari bahan alam membuktikan bahwa mikroenkapsulasi dapat membantu bahan inti tersebut menjadi lebih stabil dalam penyimpanan, menjaga umur simpan dari bahan inti menjadi lebih lama dan dapat mempertahankan aktivitas dari bahan inti tersebut. Mikroenkapsulasi dapat menjadi pilihan untuk menjaga stabilitas dari bahan alam.
\end{abstract}

Kata kunci: Bahan alam, mikroenkapsulasi, stabilitas 


\section{Pendahuluan}

Mikroenkapsulasi telah didefinisikan sebagai teknologi perlindungan bahan padat, cair dan gas dalam kapsul kecil yang melepaskan isinya dengan kecepatan terkontrol selama periode waktu yang lama(1). Mikroenkapsulasi juga dapat digunakan untuk membantu pelepasan senyawa aktif seperti polifenol, mikronutrien, enzim, antioksidan, obat-obatan dan nutraceuticals di tempat yang ditargetkan dan juga untuk meningkatkan efektivitasnya(2). Selain itu, penggunaan pelapis polimer dalam mikroenkapsulasi mempertahankan berbagai karakteristik fisikokimia senyawa inti terlindungi, termasuk sifat kelembaban dan umur simpannya ${ }^{(3)}$. Bahan dinding / polimer yang digunakan dalam proses enkapsulasi harus memiliki stabilitas tinggi, aktivitas pengemulsi tinggi dan kecenderungan untuk membentuk jaringan yang baik, sehingga mencegah terjadinya pemisahan material inti selama pemrosesan ${ }^{(4)}$.

Teknologi mikroenkapsulasi membentuk membran di sekitar bahan inti yang melindungi dari cahaya, kelembaban, $\mathrm{pH}$, dan panas. Ini biasanya digunakan untuk mengendalikan pelepasan komponen bioaktif dalam makanan fungsional dan digunakan juga di industri farmasi dengan beberapa penelitian telah melaporkan tentang efek mikroenkapsulasi pada stabilitas komponen bioaktif. Contohnya termasuk enkapsulasi likopen, karotenoid dan kurkumin ${ }^{(5)(6)(7)}$.

Teknik ini dapat mencegah kerusakan senyawa inti oleh faktor lingkungan dan juga dapat meningkatkan bioavailabilitasnya. Ini juga dapat digunakan untuk meningkatkan umur simpan produk akhir, mengurangi penguapan, dekomposisi atau reaksi dengan bahan makanan lainnya selama pembuatan, dan dapat mengontrol pelepasan senyawa aktif / inti dalam industri makanan dan farmasi(8). Mikroenkapsulasi juga banyak digunakan untuk meningkatkan stabilitas dan ketersediaan hayati senyawa bioaktif(9).

Mikroenkapsulasi menjadi salah satu teknik yang digunakan untuk melapisi atau menyegel bahan selama pemrosesan zat inti. Lebih lanjut, pendekatan ini mungkin berguna untuk melindungi senyawa yang sensitif terhadap lingkungan ${ }^{(10)}$. Salah satu cara yang dapat meningkatkan keberlanjutan senyawa sensitif adalah mikroenkapsulasi(8). Dinding atau pelapis menyediakan penghalang fisik yang mencegah difusi molekul dan reaksi kimia sehingga dapat meningkatkan stabilitas senyawa yang dienkapsulasi ${ }^{(11)}$.

Selain itu metode atau teknik enkapsulasi juga dapat membantu meningkatkan penyerapan zat aktif (slow release) pada saat masuk ke dalam jaringan tubuh sehingga fungsi zat aktif atau zat inti tersebut dapat diserap secara maksimal dalam tubuh ${ }^{(12)}$.

Tujuan dari tinjauan ini adalah untuk mengumpulkan informasi tentang penerapan sistem mikroenkapsulasi dari bahan alam. Karena dari beberapa penelitian ditemukan preparasi dari bahan alami dapat meningkatkan stabilitasnya dan memperpanjang umur simpannya. Karena diketahui kurangnya stabilitas dari bahan alam dalam penyimpanan. 


\section{Metode}

Dalam artikel tinjauan yang dibuat ini penulis menggunakan beberapa referensi yang didapatkan dari database dan dengan instrumen pencarian online yang diterbitkan secara nasional dan internasional. Referensi yang didapatkan berasal dari database elektronik seperti google scholar, sciendirect, MDPI, NCBI dari tahun 2007-2020 menggunakan kata kunci "stabilitas mikroenkapsulasi" "mikroenkapsulasi dari bahan alam".

\section{Hasil dan Pembahasan}

\section{Metode Pembuatan Mikroenkapsulasi}

Faktor-faktor yang dapat mempengaruhi kualitas dari pembuatan mikrokapsul, antara lain teknik persiapan, jenis bahan inti, dan jenis penyalut yang akan digunakan ${ }^{(13)}$. Mikroenkapsulasi memiliki beberapa metode dalam pembuatannya yang bisa disesuaikan dengan bahan atau zat yang akan dilakukan enkapsulasi sesuai dengan karakteristiknya. Berikut adalah beberapa metode pembuatan mikroenkapsulasi, metode pembuatannya dibedakan menjadi beberapa proses secara Kimia, Fisika-Kimia dan Fisika, disajikan dalam Tabel 1.

Tabel 1. Metode Pembuatan Mikroenkapsulasi ${ }^{(14)}$

\begin{tabular}{ccc}
\hline Proses Kimia & Proses Fisika-Kimia & Proses Fisika \\
\hline Polimerisasi & Koarservasi dan pemisahan & Pengeringan semprot dan \\
Antarmuka & fase & beku \\
Polimerisasi in situ & Sol-gel enkapsulasi & Fluid bed coating \\
Polikondensasi & $\begin{array}{c}\text { Mikroenkapsulasi dibantu } \mathrm{CO}_{2} \\
\text { superkritisi }\end{array}$ & Pan coating \\
& & Penguapan pelarut \\
\hline
\end{tabular}

\section{Stabilitas Bahan Alam Yang di Mikroenkapsulasi}

Mikroenkapsulasi dilakukan pada beberapa bahan alami untuk meningkatkan stabilitasnya, melindungi dari faktor lingkungan dan juga untuk meningkatkan atau menjaga aktivitas nya agar lebih efektif dan stabil. Beberapa bahan alam yang dibuat mikroenkapsulsi meliputi bahan alam, metode pembuatan dan polimer yang digunakan dapat dilihat pada Tabel 2. 
Tabel 2. Mikroenkapsulasi dari Bahan Alam dan Metode Pembuatannya

\begin{tabular}{|c|c|c|c|c|}
\hline No & Bahan Alam & Metode Pembuatan & Polimer & Referensi \\
\hline 1 & Kurkumin & $\begin{array}{l}\text { Pengeringan semprot, } \\
\text { pengeringan beku }\end{array}$ & $\begin{array}{l}\text { Maltodextrin, pati } \\
\text { jagung yang } \\
\text { dimodifikasi, gelatin, } \\
\text { pectin, inulin, tamarin } \\
\text { gum. }\end{array}$ & $(15)$ \\
\hline 2 & $\begin{array}{l}\text { Estrak } \\
\text { Hitam }\end{array}$ & pengeringan beku & $\begin{array}{l}\text { Gelatin, akasia gum, } \\
\text { kitosan, CMC }\end{array}$ & (16) \\
\hline 3 & $\begin{array}{l}\text { Ekstrak Polifenol } \\
\text { Daun Maca }\end{array}$ & Pengeringan semprot & $\begin{array}{l}\text { Maltodextrin, } \\
\text { polisakarida }\end{array}$ & (3) \\
\hline 4 & Ekstrak Saffron & $\begin{array}{l}\text { Pengeringan semprot, } \\
\text { pengeringan beku }\end{array}$ & Maltodextrin, pectin & (8) \\
\hline 5 & Chokeberry & Pengeringan semprot & Maltodextrin, susu skim & (20) \\
\hline 6 & $\begin{array}{l}\text { Ekstrak Ulmus } \\
\text { Davidiana }\end{array}$ & Pengeringan semprot & Polisakarida & (22) \\
\hline 7 & Ekstrak Sawi Putih & Pengeringan semprot & Modifikasi pati & (23) \\
\hline 8 & $\begin{array}{l}\text { Ekstrak Kubis } \\
\text { Merah }\end{array}$ & Pengeringan semprot & Modifikasi pati & (23) \\
\hline 9 & $\begin{array}{l}\text { Ekstrak Etanol } \\
\text { Spora Kapang } \\
\text { Oncom Merah }\end{array}$ & Pengeringan beku & maltodextrin & (24) \\
\hline 10 & $\begin{array}{l}\text { Ekstrak antosianin } \\
\text { dari kulit anggur }\end{array}$ & $\begin{array}{l}\text { Pengeringan semprot, } \\
\text { pengeringan beku }\end{array}$ & - & (25) \\
\hline 11 & $\begin{array}{l}\text { Likopen dari kulit } \\
\text { tomat }\end{array}$ & $\begin{array}{l}\text { Koaservasi, } \\
\text { pengeringan beku }\end{array}$ & $\begin{array}{l}\text { Isolat whey protein dan } \\
\text { gum akasia }\end{array}$ & (26) \\
\hline 12 & $\begin{array}{l}\text { Antosianin dari } \\
\text { ekstrak blueberry }\end{array}$ & Pengeringan semprot & maltodextrin & (27) \\
\hline 13 & $\begin{array}{l}\text { Fenolat kulit buah } \\
\text { delima }\end{array}$ & Pengeringan semprot & maltodextrin & (28) \\
\hline 14 & $\begin{array}{l}\text { Ekstrak Daun } \\
\text { Moringa } \\
\text { stenopetala }\end{array}$ & $\begin{array}{l}\text { Pengeringan semprot, } \\
\text { pengeringan beku }\end{array}$ & Maltodextrin & (29) \\
\hline 15 & Minyak Biji Lada & Pengeringan semprot & Maltodextrin, gum arab & (17) \\
\hline 16 & Minyak Biji Gurum & Pengeringan semprot & $\begin{array}{l}\text { Gum arab, whey } \\
\text { protein isolat }\end{array}$ & (18) \\
\hline 17 & Minyak Ikan & Pengeringan semprot & $\begin{array}{l}\text { Gum Arabic - } \\
\text { maltodextrin, casein } \\
\text { pectin - maltodextrin }\end{array}$ & (19) \\
\hline 18 & Minyak Lavender & Pengeringan semprot & $\begin{array}{l}\text { Gum akasia - } \\
\text { maltodextrin }\end{array}$ & (21) \\
\hline
\end{tabular}




\section{Mikroenkapsulasi Pada Ekstrak}

Mikropartikel kurkumin dibuat dengan cara pengeringan semprot dan pengeringan beku menggunakan beberapa capuran polimer untuk melapisi bahan inti agar diketahui juga polimer mana yang efektif sebagai polimer mikroenkapsulasi, hasil efisiensi mikroenkapsulasi pengeringan beku secara umum lebih tinggi daripada efisiensi pengeringan semprot. Hasil dari stabilitas kurkumin yang dimikroenkapsulasi terbukti meningkat dari stabilitas kurkumin yang tidak dimikroenkapsulasi, dilihat dari stabilitasnya terhadap suhu tinggi dan dalam kondisi asam ${ }^{(15)}$. Stabilitas kimia kurkumin juga dapat meningkat dengan proses mikroenkapsulasi yang dibuat dalam mikroemulsi(30). Dalam percobaan lain stabilitas kurkumin juga bertahan dalam beberapa bulan ketika dibuat dalam proses mikroenkapsulasi(31).

Ekstrak beras hitam yang dibuat mikroenkapsulasi dengan cara pengeringan beku ini juga menggunakan campuran polimer untuk melapisi bahan intinya dan dilihat dari hasilnya dapat meningkatkan kandungan antioksidan dan aktivitasnya dalam menangkal radikal bebas, dan hasil percobaan stabilitasnya yang stabil dalam kondisi penyimpanan dan juga dalam penyimpanan dengan suhu yang tinggi ${ }^{(16)}$.

Proses mikroenkapsulasi ekstrak polifenol daun maca dilakukan menggunakan metode pengeringan semprot dengan bantuan campuran polimer, hasil diketahui penggunaan campuran dari dua polimer mendapatkan hasil stabilitas ekstrak lebih baik dari yang hanya menggunakan satu polimer tunggal. Dilihat dari hasil evaluasi mikroenkapsulasi menjadikan zat inti lebih stabil dalam kondisi suhu tinggi dalam masa periode penyimpanan ${ }^{(3)}$.

Pada pembuatan mikroenkapsulasi ekstrak saffron menggunakan metode pengeringan beku dan pengeringan semprot ini juga menggunakan campuran polimer dan menghasilkan stabilitas yang dapat ditingkatkan seperti umur simpan produk jadi jika dibandingkan dengan bentuk ekstraknya. Didapatkan hasil yang dilakukan menggunakan metode pengeringan beku memiliki hasil yang lebih baik dari yang menggunakan metode pengeringan semprot ${ }^{(8)}$.

Dari hasil yang diperoleh dari mikroenkapsulasi ekstrak chokeberry menggunakan teknik pengeringan semprot, stabilitas polifenol chokeberry menunjukkan sifat yang lebih baik dibandingan dengan bentuk yang tidak dienkapsulasi. Penggunaan polimer pada enkapsulasi disini juga mempengaruhi stabilitas bahan inti menjadi lebih baik(20).

Ekstrak ulmus davidiana tidak stabil pada suhu ekstrim, juga dipengaruhi dengan adanya oksigen atau cahaya, yang biasa terjadi selama pemrosesan dan penyimpanan. oleh karena itu proses mikroenkapsulasi dilakukan untuk meningkatkan stabilitas penyimpanannya. Hasil yang didapatkan bahwa ekstrak yang dibuat kedalam mikroenkapsulasi mendapatkan dampak yang signifikan terhadap stabilitasnya ketika dalam penyimpanannya ${ }^{(22)}$. 
Dilakukan proses enkapsulasi dari ekstrak sawi putih dan kubis merah menggunakan metode pengeringan semprot dengan bantuan polimer pati yang dimodifikasi. Sebelum dienkapsulasi kedua ekstrak tersebut memiliki kelemahan stabilitas terhadap suhu yang tinggi. Ketika dilakukan proses enkapsulasi kedua ekstrak tersebut mengalami peningkatan stabilitasnya sehingga proses enkapsulasi ini menjadi pilihan untuk digunakan ${ }^{(23)}$.

Pada penelitian ekstrak etanol spora kapang oncom merah yang dilakukan mikroenkapsulasi, ekstrak etanol spora kapang oncom merah yang dienkapsulasi dengan polimer, memiliki hasil stabilitas lebih baik dibandingkan dengan ektrak etanol tanpa mikroenkapsulasi pada penyimpanan suhu ruang dan tidak ada penurunan aktivitas antioksidan selama penyimpanannya(24).

Mikroenkapsulasi sangat meningkatkan stabilitas dari antosianin ekstrak kulit anggur, terutama mikrokapsul yang dibuat dengan metode pengeringan semprot memiliki hasil yang paling stabil dalam semua pengujian yang dilakukan ${ }^{(25)}$.

Mikropartikel likopen dari kulit tomat dibuat dengan metode koaservasi kompleks dan pengeringan beku menggunakan polimer yang terdiri dari isolat whey protein dan gum akasia. Hasil dari penelitian menyebutkan bahwa enkapsulasi ini mendapatkan hasil yang stabil dalam penyimpanannya dan meningkatnya aktifitas antioksidan yang terkadung setelah dilakukan proses evaluasi(26).

Antosianin dari ekstrak bluberry dibuat mikroenkapsulasi dengan metode pengeringan semprot dengan bantuan polimer maltodextrin. Hasil mikroenkapsulasi efektif dalam perlindungan selama penyimpanan dibandingkan dengan bahan inti yang tidak dienkapsulasi, perbadingan stabilitas dilakukan dengan perlakuan yang sama antara bahan inti yang dienkapsulasi dengan bahan inti yang tidak dienkapsulasi(27).

Mikroenkapsulasi fenolat dari kulit buah delima yang dienkapsulasi dan yang tidak dienkapsulasi. Metode yang digunakan dengan cara pengeringan semprot. kedua bahan inti tersebut disimpan pada suhu $4^{\circ} \mathrm{C}$ selama 3 bulan untuk mengetahui stabilitas penyimpanan mikrokapsul serta untuk mengevaluasi efek perlindungan dari bahan pelapis / polimer pada fenolat. Hasil fenolat yang dienkapsulsi menunjukkan bahwa mikrokapsul fenolik lebih stabil daripada yang tidak dienkapsulasi(28).

Teknik mikroenkapsulasi pengeringan semprot, pengeringan beku dan jenis bahan pelapis telah menunjukkan efek signifikan pada sifat fisik, stabilitas penyimpanan, fungsional dari mikroenkapsulasi ekstrak daun moringa stenopetala. Pada stabilitas penyimpanan mikroenkapsulat yang dihasilkan dari metode pengeringan semprot secara signifikan lebih baik daripada produk yang dihasilkan dengan metode pengeringan beku (29). Proses enkapsulasi pengeringan beku lebih menguntungkan untuk menjaga senyawa yang peka terhadap panas dan mudah menguap dari ketidakstabilan, tetapi biaya pemrosesan relatif tinggi. Sebaliknya, pengeringan semprot banyak digunakan untuk mikroenkapsulasi karena pemrosesannya yang ekonomis dan penerapannya dapat digunakan dalam skala besar ${ }^{(9)}$. 


\section{Mikroenkapsulasi Pada Bahan Alam Minyak}

Dalam beberapa tahun terakhir, mikroenkapsulasi minyak dalam matriks polimer telah digunakan untuk melindunginya dari degradasi oksidatif dan dapat melindungi dari rasa yang tidak enak serta bau yang tidak sedap. Sehingga stabilitasnya lebih terjaga dari proses oksidasi(32).

Dalam mikroenkapsulasi minyak biji lada proses mikroenkapsulasi dilakukan dengan metode pengeringan semprot dengan menggunakan campuran polimer. Mikroenkapsulasi terbukti dapat memperbaiki sifat asli dari minyak biji lada yang sangat peka terhadap kondisi lingkungan dan juga meningkatkan stabilitas yang signifikan minyak biji lada terhadap oksidasi selama penyimpanan dibandingkan dengan minyak biji lada yang tidak dibuat mikroenkapsulasi ${ }^{(17)}$. Pembuatan mikroenkapsulasi minyak biji gurum juga menggunakan campuran polimer untuk enkapsulasinya dan dilakukan menggunakan metode pengeringan semprot. Pembuatan mikroenkapsulasi ini juga mampu meningkatkan stabilitas yang lebih baik terhadap oksidasi dari minyak biji gurum yang tidak dilakukan mikroenkapsulasi ${ }^{(18)}$.

Pada mikroenkapsulasi minyak ikan dilakukan dengan menggunakan metode pengeringan semprot. Diketahui minyak ikan lebih mudah teroksidasi selama dalam penyimpanan. Setelah proses enkapsulasi dengan campuran polimer yang digunakan didapatkan hasil mikroenkapsulasi dapat meningkatkan stabilitas minyak ikan terhadap oksidasi menjadi lebih stabil dalam kondisi penyimpanan sehingga meningkatkan masa simpannya ${ }^{(19)}$.

Stabilitas minyak lavender yang dienkapsulasi menggunakan metode pengeringan semprot menunjukan stabilitas yang lebih baik dalam proses penyimpanan. Dimana diketahui bahwa minyak tersebut tidak hanya tidak stabil dalam penyimpanan tetapi juga mudah menguap secara alami. Dengan demikian proses bentuk yang sudah dienkapsulasi juga menjadi mudah untuk ditangani. Proses ini dilakukan menggunakan polimer campuran yang dapat melindungi komponen minyak yang akan dienkapsulasi(21).

\section{Kesimpulan}

Mikroenkapsulasi menjadi salah satu cara untuk meningkatkan stabilitas bahan inti yang berasal dari bahan alam, meningkatkan masa simpan, sebagai pengontrol pelepasan zat inti, dan dapat melidungi aktivitas zat inti dari gangguan eksternal. Mikroenkapsulasi juga dapat menjadi pilihan agar zat inti yang terbuat dari bahan alam dapat meningkat umur simpannya. Enkapsulasi dibantu oleh penggunaan polimer yang mempunyai tujuan atau kegunaan sebagai penyalut dari zat inti juga sebagai zat penstabil atau pelindung dari gangguan eksternal zat inti yang tersalut. Sehingga zat inti dapat terlindung dan terjaga stabilitasnya. Metode mikroenkapsulasi bisa menjadi pilihan untuk digunakan untuk membantu menjaga stabilitas zat inti dari bahan alam. 


\section{Ucapan Terimakasih}

Penulis menyampaikan ucapan terima kasih kepada lbu Prof. Dr. apt. Marline Abdassah, MS, Ibu Dr. rer. nat. apt. Anis Yohana Chaerunisaa, M.Si. selaku pembimbing dalam proses pembelajaran, penelitian tugas akhir penulis dan yang telah memberikan bimbingannya selama penulisan artikel review ini.

\section{Daftar Pustaka}

1. Champagne CP, Fustier P. Microencapsulation for the improved delivery of bioactive compounds into foods. Curr Opin Biotechnol. 2007;18(2):184-90.

2. Ezhilarasi PN, Karthik P, Chhanwal N, Anandharamakrishnan C. Nanoencapsulation Techniques for Food Bioactive Components: A Review. Food Bioprocess Technol. 2013;6(3):628-47.

3. Lee $\mathrm{YK}$, Chang $\mathrm{YH}$. Microencapsulation of a maca leaf polyphenol extract in mixture of maltodextrin and neutral polysaccharides extracted from maca roots. Int $\mathrm{J}$ Biol Macromol [Internet]. 2020;150:546-58. Available from: https://doi.org/10.1016/j.ijbiomac.2020.02.091

4. Polekkad A, Franklin MEE, Pushpadass HA, Battula SN, Rao SBN, Pal DT. Microencapsulation of zinc by spray-drying: Characterisation and fortification [Internet]. Vol. 381, Powder Technology. Elsevier B.V; 2021. 1-16 p. Available from: https://doi.org/10.1016/j.powtec.2020.12.009

5. Cheng YS, Lu PM, Huang CY, Wu JJ. Encapsulation of lycopene with lecithin and $\alpha-$ tocopherol by supercritical antisolvent process for stability enhancement. J Supercrit Fluids [Internet]. 2017;130:246-52. Available from: http://dx.doi.org/10.1016/j.supflu.2016.12.021

6. Mansour M, Salah M, Xu X. Effect of microencapsulation using soy protein isolate and gum arabic as wall material on red raspberry anthocyanin stability, characterization, and simulated gastrointestinal conditions. Ultrason Sonochem [Internet]. 2020;63(December 2019):104927. Available from: https://doi.org/10.1016/j.ultsonch.2019.104927

7. Neves MIL, Desobry-Banon S, Perrone IT, Desobry S, Petit J. Encapsulation of curcumin in milk powders by spray-drying: Physicochemistry, rehydration properties, and stability during storage. Powder Technol. 2019;345:601-7.

8. Ahmadian Z, Niazmand R, Pourfarzad A. Microencapsulation of Saffron Petal Phenolic Extract: Their Characterization, In Vitro Gastrointestinal Digestion, and Storage Stability. J Food Sci. 2019;84(10):2745-57.

9. Gharsallaoui A, Roudaut G, Chambin O, Voilley A, Saurel R. Applications of spraydrying in microencapsulation of food ingredients: An overview. Food Res Int. 2007;40(9):1107-21.

10. Lee $\mathrm{YK}$, Chang $\mathrm{YH}$. Microencapsulation of a maca leaf polyphenol extract in mixture of maltodextrin and neutral polysaccharides extracted from maca roots. Int $\mathrm{J}$ Biol Macromol [Internet]. 2020;150:546-58. Available from: https://doi.org/10.1016/j.ijbiomac.2020.02.091

11. Taguchi Y, Saito N, Uchida A, Tanaka M. Preparation of Thermosensitive Microcapsules Containing Water Soluble Powder by Melting Dispersion Cooling Method. J Encapsulation Adsorpt Sci. 2016;06(03):57-69. 
12. Septevani AA, Sondari D, Ghozali M. Pengaruh Teknik Pengeringan Semprot (Spray Drying) dalam Mikroenkapsulasi Asiaticoside dan Ekstrak Jahe. Indones Jounal Mater Sci. 2013;14(4):248-52.

13. Peanparkdee $M$, Iwamoto $S$, Yamauchi R. Microencapsulation: a Review of Applications in the Food and Pharmaceutical Industries. Rev Agric Sci. 2016;4(0):56-65.

14. Coatings F. Automotive Paints and Coatings Multilayer Thin Films High Performance Pigments Colloids and Colloid Assemblies. Organization. 2006.

15. Guo J, Li P, Kong L, Xu B. Microencapsulation of curcumin by spray drying and freeze drying. Lwt [Internet]. 2020;132(July):109892. Available from: https://doi.org/10.1016/j.Iwt.2020.109892

16. Kanha N, Surawang S, Pitchakarn P, Laokuldilok T. Microencapsulation of copigmented anthocyanins using double emulsion followed by complex coacervation: Preparation, characterization and stability. Lwt [Internet]. 2020;133(September):110154. Available

from: https://doi.org/10.1016/j.Iwt.2020.110154

17. Karaaslan M, Şengün F, Cansu Ü, Başyiğit B, Sağlam H, Karaaslan A. Gum arabic/maltodextrin microencapsulation confers peroxidation stability and antimicrobial ability to pepper seed oil. Food Chem. 2021;337(July 2020).

18. Karrar E, Mahdi AA, Sheth S, Mohamed Ahmed IA, Manzoor MF, Wei W, et al. Effect of maltodextrin combination with gum arabic and whey protein isolate on the microencapsulation of gurum seed oil using a spray-drying method. Int $\mathrm{J}$ Biol Macromol [Internet]. 2021;171:208-16. Available from: https://doi.org/10.1016/j.ijbiomac.2020.12.045

19. Vaucher AC dos S, Dias PCM, Coimbra PT, Costa I dos SM, Marreto RN, Dellamora-Ortiz GM, et al. Microencapsulation of fish oil by casein-pectin complexes and gum arabic microparticles: oxidative stabilisation. J Microencapsul [Internet]. 2019;36(5):459-73. Available

from: http://dx.doi.org/10.1080/02652048.2019.1646335

20. Ćujić-Nikolić N, Stanisavljević N, Šavikin K, Kalušević A, Nedović V, Samardžić J, et al. Chokeberry polyphenols preservation using spray drying: effect of encapsulation using maltodextrin and skimmed milk on their recovery following in vitro digestion. $J$ Microencapsul [Internet]. 2019;36(8):693-703. Available from: https://doi.org/10.1080/02652048.2019.1667448

21. Burhan AM, Abdel-Hamid SM, Soliman ME, Sammour OA. Optimisation of the microencapsulation of lavender oil by spray drying. J Microencapsul [Internet]. 2019;36(3):250-66. Available from: https://doi.org/10.1080/02652048.2019.1620355

22. Choi YR, Chang YH. Microencapsulation of gallic acid through the complex of whey protein concentrate-pectic polysaccharide extracted from Ulmus davidiana. Food Hydrocoll. 2018;85:222-8.

23.Zanoni F, Primiterra M, Angeli N, Zoccatelli G. Microencapsulation by spray-drying of polyphenols extracted from red chicory and red cabbage: Effects on stability and color properties. Food Chem [Internet]. 2020;307:125535. Available from: https://doi.org/10.1016/j.foodchem.2019.125535 
24. Kimia J, Tadulako U, Bumi K, Tondo T. AKTIVITAS ANTIOKSIDAN MIKROKAPSUL EKSTRAK ETANOL KAPANG ONCOM MERAH ( Neurospora sp ) [Antioxydant Activity of Microcapsul Etanol Extract of Neurospora sp ] Aini Auliana Amar 1, Syaiful Bahri 1*, Mappiratu 1. 2018;4(2):145-51.

25.Zhang R, Zhou L, Li J, Oliveira H, Yang N, Jin W, et al. Microencapsulation of anthocyanins extracted from grape skin by emulsification/internal gelation followed by spray/freeze-drying techniques: Characterization, stability and bioaccessibility. Lwt [Internet]. 2020;123(January):109097. Available from: https://doi.org/10.1016/j.lwt.2020.109097

26. Gheonea (Dima) I, Aprodu I, Cîrciumaru A, Râpeanu G, Bahrim GE, Stănciuc N. Microencapsulation of lycopene from tomatoes peels by complex coacervation and freeze-drying: Evidences on phytochemical profile, stability and food applications. J Food Eng. 2020;288(March 2020).

27. Righi da Rosa J, Nunes GL, Motta MH, Fortes JP, Cezimbra Weis GC, Rychecki Hecktheuer $\mathrm{LH}$, et al. Microencapsulation of anthocyanin compounds extracted from blueberry (Vaccinium spp.) by spray drying: Characterization, stability and simulated gastrointestinal conditions. Food Hydrocoll. 2019;89:742-8.

28. Çam M, Içyer NC, Erdoğan F. Pomegranate peel phenolics: Microencapsulation, storage stability and potential ingredient for functional food development. LWT Food Sci Technol. 2014;55(1):117-23.

29. Dadi DW, Emire SA, Hagos AD, Eun JB. Physical and Functional Properties, Digestibility, and Storage Stability of Spray- and Freeze-Dried Microencapsulated Bioactive Products from Moringa stenopetala Leaves Extract. Ind Crops Prod [Internet]. 2020;156(July 2019):112891. Available from: https://doi.org/10.1016/j.indcrop.2020.112891

30. Jiang T, Liao W, Charcosset C. Recent advances in encapsulation of curcumin in nanoemulsions: A review of encapsulation technologies, bioaccessibility and applications. Food Res Int [Internet]. 2020;132(January):109035. Available from: https://doi.org/10.1016/j.foodres.2020.109035

31. Kocer Z, Aru B, Sezer UA, Demirel GY, Beker U, Sezer S. Process optimisation, biocompatibility and anti-cancer efficacy of curcumin loaded gelatine microparticles cross-linked with dialdeyhde carboxymethyl cellulose. J Microencapsul [Internet]. 2019;36(5):485-99. http://dx.doi.org/10.1080/02652048.2019.1646337

32. Le Priol L, Dagmey A, Morandat S, Saleh K, El Kirat K, Nesterenko A. Comparative study of plant protein extracts as wall materials for the improvement of the oxidative stability of sunflower oil by microencapsulation. Food Hydrocoll [Internet]. 2019;95(January):105-15. Available from: https://doi.org/10.1016/j.foodhyd.2019.04.026 